\title{
ISSUES RELATING TO THE PRACTICAL USE OF TRANSGENIC CROPS FOR INSECT PEST MANAGEMENT
}

\author{
D.A.J. TEULON ${ }^{1}$ and J.E. LOSEY ${ }^{2}$ \\ ${ }^{I}$ New Zealand Institute for Crop \& Food Research Limited, Private Bag 4704, \\ Christchurch, New Zealand \\ ${ }^{2}$ Department of Entomology, Cornell University, Ithaca, New York, USA \\ Corresponding author: teulond@crop.cri.nz
}

\begin{abstract}
The implementation of transgenic plants for insect pest management requires a thorough evaluation of the risks, costs and benefits. Currently, all commercialised transgenic crops for insect control contain genes expressing specific $B t$ toxins. Excluding environmental and human health concerns, the most apparent risk for these $B t$-plants is development of resistance to $B t$ toxins. The high dose/refuge strategy is accepted as most likely to delay or prevent pest resistance development. This strategy is based on the best available information but has several incompletely tested assumptions. The high dose/refuge strategy requires detailed knowledge of the plant-insect system and its implementation involves rigorous crop management. There have been few documented instances of harmful impacts on predators and parasitoids from transgenic plants expressing $B t$ or other toxins. The costs and benefits of using transgenic plants will depend on several factors including the plant species, its complex of insect pests, environmental conditions and alternative pest management tools and systems such as Integrated Pest Management. Benefits of transgenic plants are most likely to outweigh costs and risks for insects that are difficult to control by any other method and/or require numerous insecticide applications.

Keywords: transgenic plants, Bacillus thuringiensis, insect pest
\end{abstract} management, resistance management, non-target impacts.

\section{INTRODUCTION}

Transgenic plants have the potential to reduce management costs and the impacts of pests, diseases and weeds in agricultural systems and are presently used in about thirteen countries. In 2001 the estimated area of transgenic crops was $52.6 \mathrm{~m}$ ha, an increase of $19 \%$ over 2000. James (2002) details the main countries growing transgenic crops as well as the main crops and transgenic traits. New Zealand, like many European countries, has taken a more cautious approach to the introduction of transgenic crops than the USA; no commercial releases have so far taken place (Anon. 2001a; Christey \& Woodfield 2001). The recently completed Royal Commission on Genetic Modification (Anon. 2001a) concluded that it would be unwise for New Zealand to turn its back on the potential advantages of genetic modification but that it should proceed carefully, minimising and managing risks to encourage the coexistence of all forms of agriculture (Anon. 2001a). While there have been numerous reviews on the risks and benefits of transgenic crops in relation to their impact on the environment and humans, it is worth examining the benefits and costs of transgenic plants as they relate to their practical implementation and use for pest management. This paper considers these in the New Zealand context with particular emphasis on insect pest management. For the sake of brevity, review articles are referenced rather than original source documents.

\section{HISTORICAL PERSPECTIVE}

The introduction of new technologies in pest management has been typically problematic in New Zealand and elsewhere. The initial overuse of synthetic insecticides 
soon led to many unforeseen impacts including pest resurgence, environmental contamination, impacts on natural systems and human health issues (e.g. MacIntyre et al. 1989). In addition, there has been increasing concern about the impact of intentionally introduced biological control agents on non-target organisms such as New Zealand's indigenous fauna (Cullen 1997). While it is difficult to quantify the degree of these impacts, and to place them alongside the benefits received from these technologies, it is clear that some of the impacts could have been minimised. Subsequent legislation, based on a greater understanding of the agricultural and natural systems involved, has led to strict limitations on the range and use of pesticides and, especially in New Zealand, to restrictions on the release of biological control agents (Hazardous Substances and New Organism Act 1996). Like synthetic insecticides, transgenic plants have the potential to spread novel toxins through agricultural systems and, like biological control agents, transgenic crops may be very difficult to eradicate. The unwanted movement of genes into the environment from transgenic plants may pose more of a management dilemma than unwanted chemicals (Ellstrand 2001).

The speed with which developments in transgenic technology are occurring, the greater sophistication of environmental assessments, the growing public concern about environmental degradation, and the lack of faith in government oversight to prevent that degradation (National Research Council 2002), means the use of transgenic plants is a central focus of scientific and public debate.

\section{THE PRE-EMINENCE OF BACILLUS THURINGIENSIS}

Bacillus thuringiensis $(B t)$ is a naturally occurring soil bacterium which produces crystal protein delta-endotoxins that are toxic to insects. Its role in nature is not well understood but it has become the most important bio-pesticide, accounting for about $90 \%$ (over 100 products) of all commercial bio-pesticide sales worldwide (Glare \& O'Callaghan 2000). Crops transformed with genes derived from $\mathrm{Bt}$ are also the most common transgenic plants released into the environment (James 2002; Letourneau et al. 2002).

The compelling rationale for $B t$ use in transgenic plants (and bio-pesticides) relates to the number and variety of $B t$ toxins, the specificity of these toxins to different organisms (especially Lepidoptera, Coleoptera and Diptera), their relatively low toxicity to some non-target organisms including humans, and the extensive body of knowledge on their biology, ecology and safety (see Glare \& O'Callaghan 2000). Although enhanced resistance of plants to pests has been demonstrated with other transgenes, such as proteinase inhibitors and lectins, the level of expression has not been sufficient for their commercialisation (Hilder \& Boulter 1999).

There are a number of significant differences between transgenic Bt-plants and $B t$-biopesticides. Typically bio-pesticides are made from mixtures of $B t$ toxins, whereas $B t$-plants express only one toxin. Also, $B t$-plants generally express the toxin throughout the plant and for the duration of the growing cycle while $B t$-bio-pesticides degrade quickly when exposed to UV light (Glare \& O'Callaghan 2000). Furthermore, because bacterial genes do not express well in plants, the transgenic $B t$ genes have been substantially modified. They are often truncated and engineered to produce up to 100 times higher expression in plants (Hilder \& Boulter 1999; Andow 2002). Significantly, many $B t$ genes in transgenic crops are modified so that they are toxic without the need for proteolytic activation in the insect gut (Groot \& Dicke 2001). The ubiquitous and continuous availability of these highly expressed toxins in $B t$-plants has important implications for their use in the field, as will be discussed below, and necessitates new risk assessment techniques to take these differences into account (Jepson et al. 1994).

\section{IMPACT ON BENEFICIAL ORGAMISMS}

The high expression of toxins in transgenic plants throughout their growing seasons has the potential to disrupt the beneficial role of predators, parasitoids and other 
organisms through direct feeding on the $B t$-plant, feeding on herbivores on the $B t$-plants or exposure in the soil (Groot \& Dicke 2001). Conversely, the exclusive use of specific $B t$-toxins to target key pests has the potential to reduce the use of broad spectrum insecticides and thus lessen the impact on biological control agents. Target pests for $B t$-plants are most likely to be Lepidoptera, Coleoptera and Diptera. As most (99\%) Lepidoptera are phytophagous Bt-plants targeting this group are unlikely to interfere with natural enemies of pests. However, many Lepidoptera are important for pollination and biological control of weeds so negative impacts within this order could interfere with vital ecosystem services (see Losey et al. 2002). In contrast, a considerable proportion of Coleoptera $(65 \%)$ and Diptera $(70 \%)$ are carnivores or saprophytes (Groot \& Dicke 2001), both of which have important roles in agro-systems.

To date, most laboratory and field reports have indicated that transgenic plants containing $B t$ toxins, as well as other transgenic traits, such as proteinase inhibitors and lectins, have little direct effect on populations of natural enemies (Sharma \& Ortiz 2000; Groot \& Dicke 2001). Nevertheless, several instances of negative impacts on natural enemies have been reported, indicating the complexity of tri-trophic interactions between plants, herbivores and natural enemies (Ashouri et al. 1998; Hilbeck 2002). There are also a number of reports on negative impacts on honeybees for some toxins used in transgenic plants but not Bt-plants (Groot \& Dicke 2001; Malone et al. 2001). Overall, while the current paucity of proven negative results is positive, this may be partly due to the inability of current risk assessment procedures to adequately address the complexity of ecosystems (Obrycki et al. 2001; Hilbeck 2002).

\section{INSECT RESISTANCE MANAGEMENT}

The most pressing issue relating to the practical implementation of transgenic plants in agricultural systems is the potential for rapid development of insect resistance due to the strong temporal and spatial selection pressure of $B t$ toxins controlled by a single gene (Groot \& Dicke 2001; Andow 2002; Shelton et al. 2002). Already, about 17 insect species have become resistant to $B t$ in the laboratory, but only one species has shown widespread resistance in the field (Glare \& O'Callaghan 2000). It is widely considered to be only a matter of time before resistance occurs in Bt-plants (Andow 2002). In addition to the costs associated with the loss of the product and the development of alternative control strategies (either transgenic or conventional), the development of resistance will jeopardise the use of related Bt-bio-pesticides for all users including those not using transgenic technologies (McGaughey et al. 1998).

In the USA in particular, insect resistance management (IRM) strategies to delay or prevent resistance in Bt-plants are being developed as a matter of high priority. The Environmental Protection Agency in the USA has imposed requirements on industry (e.g. EPA 2000a,b,c), as part of the Bt-plant registration. These require industry to adhere to recognised IRM strategies and to monitor the development of resistance in crops so that its impact can be moderated if it occurs. The most accepted IRM strategy, and the strategy most likely to be implemented in New Zealand (Cameron et al. 2002), is the high dose/refuge strategy. This is based on the production of very high toxin concentrations (e.g. 25-50 LC Lo $_{50}$ for corn) in $B t$-plants with nearby refuges of nontransgenic plants (Andow 2002). Refuges may include within or between row plant mixtures but in most cases areas of non-transgenic plants external to the transgenic crop have been preferred (Table 1) (Grott \& Dicke 2001). Determination of the size of refuges is a compromise between practical and commercial considerations which favour smaller refuges and scientific theory which favours larger refuges (Gould 2000; Shelton et al. $2000)$. The size of refuges is further complicated by some farmers failing to plant them at all (Anon. 2001b). 
TABLE 1: Size of refuges for three commercialised transgenic crops in the USA.

\begin{tabular}{lcccc}
\hline Crop & Untreated & Treated $^{1}$ & Distance & Reference \\
\hline Potato & $20 \%$ & $20 \%$ & $<3.2 \mathrm{~km}$ & EPA 2000a \\
Corn & $20 \%(50 \%)^{2}$ & $20 \%(50 \%)$ & $0.8 \mathrm{~km}(0.4 \mathrm{~km})^{3}$ & $\begin{array}{c}\text { Andow 2002; EPA 2000b } \\
\text { Chelton et al. 2000; EPA 2000c }\end{array}$ \\
Cotton & $4 \%$ & $20-25 \%$ & & Sh
\end{tabular}

${ }^{1}$ Treated using IPM recommendations but not with $B t$ bio-pesticides.

${ }^{2} 50 \%$ in areas where corn and cotton are grown together as corn earworm feeds on both crops.

${ }^{3}$ In regions of high insecticide use $0.4 \mathrm{~km}$ is the recommended distance for corn.

The high dose/refuge strategy relies on three essential assumptions: (1) insecticide resistance is functionally recessive with a high dose, (2) resistance alleles in insects are rare $\left(<10^{-3}\right)$, and $(3)$ random mating between insects surviving on transgenic plants and susceptible insects in refuges (Andow 2002). While this strategy is based on the best information available, some recent findings bring these assumptions into question. Resistance may not always be recessive (Groot \& Dicke 2001) and resistance alleles may be more common than previously thought. For example, a frequency of 0.16 has been found in pink bollworm on $B t$-cotton (Tabashnik et al. 2000a). Random mating between resistant populations on $B t$-plants and susceptible populations in refuges may be suppressed by a number of factors including different development times for populations on Bt and non-Bt plants (Groot \& Dicke 2001).

A number of other factors may influence the effectiveness of the high dose/refuge strategy. Not all Bt-plants have a high dose and at least some non-high dose Bt-corn varieties are now being withdrawn from the market in the USA (Andow 2002). Low dose may occur as a result of low toxin expression in some plant parts and/or with plant maturity. This has been implicated as a factor in the loss of control in some Bt crops (Hilder \& Boulter 1999; Adamczyk et al. 2001a; Archer et al. 2001). Also, some insect instars may be less susceptible to the toxin than others (Halcomb et al. 1996). Some insects may move from transgenic to non-transgenic plants where plant mixtures are used (Gould 2000; Groot \& Dicke 2001). Presumably, the high dose/refuge strategy will be unlikely to be effective with insects species such as aphids and thrips that do not always undergo sexual reproduction.

The high dose/refuge strategy is further complicated where multiple pests and crops are considered (Gould 1994). Secondary pests may have a higher tolerance to Bt toxins than target pests and require a higher expression of toxin to avoid resistance (Storer et al. 2001). Where the same pest occurs on different Bt-plants with the same toxin, the size of refuges may need to be increased dramatically (Andow 2002) (see Table 1). Transgenic plants stacked with genes for two different pests that have different modes of movement (e.g. flying European corn borer and walking corn rootworm) may need complex refuges of mixed rows and external crop refuges. Previous exposure and resistance as well as cross resistance will also need to be considered (Tabashnik et al. $2000 \mathrm{~b}, \mathrm{c})$. Thus, the optimal spatial and temporal scale of refuges is likely to be unique for each insect-plant interaction to cope with local variation in pest complexes, crops and cropping practices (Sharma \& Ortiz 2000; Shelton et al. 2000; Carrière et al. 2001).

Stacking genes for two different $B t$ toxins in a plant for the same target pest (Sharma \& Ortiz 2000), and for secondary pests (Adamczyk et al. 2001b), and hyper-expression of the toxin through chloroplast engineering (De Cosa et al. 2001) are methods that may help to reduce the development of resistance in the future.

In New Zealand, IRM strategies are being considered for two Bt-crops (Cameron et al. 2002). Results to date suggest that sufficient potato tuber moths would forage between adjacent transgenic and non-transgenic potato crops to minimise the development of insecticide resistance. However, preliminary research indicates this may not be true for 
the diamond back moth in brassica crops (Cameron et al. 2002). IRM strategies for diamond back moth require special attention because this insect has already developed resistance to $B t$ biopesticides in several countries (Shelton et al. 2002). The relatively long time for potato tuber moths to die and their enhanced movement would preclude mixed plantings for resistance management for this insect on the Bt-potatoes tested (Cameron et al. 2002).

\section{BENEFITS FROM TRANSGENIC CROPS}

The premiums farmers pay for transgenic crops may be compensated for by increased returns (increased quality and yield) and decreased input costs (reduced insecticide, labour and equipment usage) (Letourneau et al. 2002). These benefits vary according to a number of factors as the following three examples illustrate.

$B t$-potato, for control of the Colorado potato beetle, became the first $B t$-plant to be commercialised in 1995. While reduced insecticide applications were reported (Gianessi \& Carpenter 1999), Bt-potato had a maximum market penetration of about $4 \%$ and is now no longer produced. Reasons for its lack of success include perceived detrimental agronomic properties, its narrow spectrum for control, competition from a new and effective insecticide and consumer resistance (Andow 2002; Shelton et al. 2002).

Since 1996, several Bt constructs have been incorporated into corn for protection against European corn borer (ECB) and other Lepidoptera (Andow 2002). While Bt-corn has a high adoption rate (up to $26 \%$ in 1999) (Carpenter \& Gianessi 2001) it has also generated the most debate in terms of its economic benefit and ecological impact. The main benefit is through increased yield with negligible reduction in insecticide use because very few farmers normally spray for this pest (Carpenter \& Gianessi 2001; Letourneau et al. 2002). In years of low ECB infestation the economics of planting $B t$-corn are questionable, at least in some areas. This may be reflected in the recent decline in its use in 2000 although low pest pressure in previous years has also been implicated in this reduction (Hyde et al. 1999; Carpenter \& Gianessi 2001; Letourneau et al. 2002). There has been recent strong criticism on the use of $B t$-corn as a prophylactic treatment in years when it is not needed (Obrycki et al. 2001; Obrycki 2001), although this view is not universal (Ortman et al. 2001). Benefits in the form of reduced insecticide use may be much more significant with sweetcorn because intense schedule insecticide applications are common for this crop (Letourneau et al. 2002; Shelton et al. 2002).

Bt-cotton was released in 1996 to protect against tobacco budworm, cotton bollworm and pink bollworm. Between five and twelve insecticide applications are needed to control these important pests (Shelton et al. 2002) and even though there appear to be significant yield increases with Bt-cotton, the major benefit is attributed to the lower insecticide use and corresponding lower input costs for farmers (Gianessi \& Silvers 2001; Letourneau et al. 2002). Nevertheless, insecticide use on Bt-cotton still remains high in some areas, sometimes as high as on conventional cotton, due to the requirement to control other insects not affected by the $B t$ toxin (Carpenter \& Gianessi 2001; Hilbeck 2002). Where there is a complex of pests, transgenic crops do not eliminate the need for farmers to remain vigilant in monitoring insects pests and in some cases may not affect insecticide use patterns (Andow 2002).

For good reasons, most comparisons illustrating the benefits of transgenic crops have been made with conventional agricultural practices (Letourneau et al. 2002). However, these benefits may or may not be valid when Bt-crops are compared with other management systems. For example, Integrated Pest Management (IPM) systems have lead to dramatic reductions in insecticide use in apple (90\% of broad spectrum insecticides) (Walker et al. 2001), kiwifruit (63\% of broad spectrum insecticides) (Suckling et al. 2002), processing tomatoes ( $90 \%$ of total insecticides) (G. Walker, unpubl. data) and brassicas (50-65\% of total insecticides) (Anon. 2000) in New Zealand. The costs and benefits of IPM and transgenic crops should be critically appraised, especially in New Zealand, where there has been a strong history of successful implementation of IPM programmes. 


\section{IPM AND TRANSGENIC PEST CONTROL}

Until recently the dominant paradigm in insect pest management has been IPM, which developed in response to the overuse of synthetic insecticides in the 1950s and 1960s (Dent 1991). The objective of IPM is to use all methods available to reduce the pest populations below levels where they cause economic damage in an environmentally sustainable fashion (Dent 1991). A central tenet of IPM is to only apply insecticides at thresholds when insect numbers reach levels where economic damage is likely to occur.

Transgenics provide an interesting conundrum for IPM. On the one hand there are parallels between the use of transgenics and the use of scheduled insecticide applications in relation to the high spatial and temporal use of toxins. Both systems may delay the development of ecologically based pest management, and pursue a genetic treadmill of solutions in the race against resistance (van Emden 1999; Groot \& Dicke 2001; Hilbeck 2002). Transgenic plant pollen and root exudates are another form of insecticide drift. Conversely, the present commercially available transgenic plants are almost certainly safer than the intensive use of chemical pesticides (Sharma \& Ortiz 2000). Thus, one of the great challenges in pest management is to evaluate how and whether transgenic plants can be incorporated as safe, effective components of sustainable IPM systems (Hilbeck 2002).

\section{CONCLUSIONS}

Transgenic plants have the potential to increase crop yield and reduce insecticide use in agricultural systems in New Zealand. However, the benefits of transgenic technology will depend on several factors including the plant species, its complex of insect pests, environmental conditions and alternative pest management tools and systems. Benefits will be most obvious for insects that are difficult to control by any other method and/or require numerous insecticide applications and have minimal environmental impact. The present emphasis on $B t$ toxins minimises impacts on biological control agents but this may not be true for other transgenes. Excluding the potential negative environmental impacts, the most serious threat for sustainable use of transgenics is insecticide resistance and the loss of the use of $B t$ toxins as biopesticides. Insect resistance management strategies are complex and require significant resources for their development and maintenance. In contrast to some expectations, it is likely that systems based on Bt-plants will require more, not less, management input than conventional crops (Fitt \& Wilson 2000).

\section{ACKNOWLEDGEMENTS}

This work was carried out in association with a Crop \& Food Research Fellowship to Dr David Teulon to visit Cornell University in 2001. The senior author thanks Professor Donald Rutz (Chair, Department of Entomology, Cornell University) for making available the necessary space and facilities at Cornell.

\section{REFERENCES}

Adamczyk, J.J.Jr.; Hardee, D.D.; Adams, L.C.; Sumerford, D.V. 2001a: Correlating differences in larval survival and development of bollworm (Lepidoptera: Noctuidae) and fall armyworm (Lepidoptera: Noctuidae) to different expression of Cry1A(c) $\delta$-Endotoxin in various plant parts among commercial cultivars of transgenic Bacillus thuringiensis cotton. J. Econ. Entomol. 94: 284-290.

Adamczyk, J.J.Jr.; Adams, L.C.; Hardee, D.D. 2001b: Field efficacy and seasonal expression profiles for terminal leaves of single and double Bacillus thuringiensis toxin cotton genotypes. J. Econ. Entomol. 94: 1589-1593.

Andow, D.A. 2002: Resisting resistance to Bt-corn. In: Letourneau, D.K.; Burrows, B.E. ed. Genetically modified organisms. Assessing environmental and human health effects. CRC Press, Boca Raton. Pp. 99-124. 
Anon. 2000: Cabbage growers step off the pesticide treadmill. Digest 30: 3. New Zealand Institute for Crop \& Food Research Limited, Christchurch.

Anon. 2001a: Report of the Royal Commission on Genetic Modification. Royal Commission on Genetic Modification, Wellington, New Zealand. $465 \mathrm{p}$.

Anon. 2001b: Nowhere to hide. New Scientist 169 (2277): 15.

Archer, T.L.; Patrick, C.; Schuster, G.; Cronholm, G.; Bynum, E.D.Jr.; Morrison, W.P. 2001: Ear and shank damage by corn borers and corn earworms to four events of Bacillus thuringiensis transgenic maize. Crop Prot. 20: 139-144.

Ashouri, A.; Overney, S.; Michaud, D.; Cloutier, C. 1998: Fitness and feeding are affected in the two-spotted stinkbug, Perillus bioculatus, by the cysteine proteinase inhibitor, oryzacystatin I. Arch. Insect Biochem. Physiol. 38: 74-83.

Cameron, P.J.; Walker, G.P.; Penny, G.M.; Wigley, P.J. 2002: Movement of potato tuberworm (Lepidoptera: Gelechiidae) within and between crops and some comparisons with diamond back moth (Lepidoptera: Plutellidae). Environ. Entomol. 31: 65-75.

Carpenter, J.E.; Gianessi, L.P. 2001: Agricultural biotechnology: updated benefit estimates. Agricultural biotechnology: insect control benefits. National Center for Food and Agricultural Policy, Washington. http://www.ncfap.org/ (16/5/ 2002).

Carrière, Y.; Dennehy, T.J.; Pedersen, B.; Haller, S.; Ellers-Kirk, C.; Antilla, L.; Liu, Y.B.; Willott, E.; Tabahnik, B.E. 2001: Large-scale management of insect resistance to transgenic cotton in Arizona: can transgenic insecticide crops be sustained? J. Econ. Entomol. 94: 315-325.

Christey, M.; Woodfield, D. 2001: Coexistence of genetically modified and nongenetically modified crops. Report prepared for the Ministry for the Environment. Crop \& Food Research Confidential Report No. 427. New Zealand Institute for Crop \& Food Research Limited, Christchurch, New Zealand. 27 p.

Cullen, J.M. 1997: Biological control and impacts on non-target species. Proc. 50th N.Z. Plant Prot. Conf.: 195-201.

De Costa, B.; Moar, W.; Lee, S.B.; Miller, M.; Daniell, H. 2001: Overexpression of the Bt cry2Aa2 operon in chloroplasts leads to formation of insecticidal crystals. Nature Biotechnol. 19: 71-74.

Dent, D. 1991: Insect Pest Management. CAB International, Wallingford. 604 p.

Ellstrand, N.C. 2001: When transgenes wander, should we worry? Plant Physiol. 125: $1543-1545$.

EPA 2000a. Biopesticide Fact Sheet. Bacillus thuringiensis CryIII(A) Delta endotoxin and the genetic material necessary for its production in potato. US Environmental Protection Agency, Washington, DC. http://www.epa.gov/pesticides/biopesticides/ factsheets/fs006432t.htm (16/5/2002).

EPA 2000b. Biopesticide Fact Sheet. Bacillus thuringiensis CryIAb Delta Endotoxin and the genetic material necessary for its production in corn [MON 810]. US Environmental Protection Agency, Washington, DC. http://www.epa.gov/pesticides/ biopesticides/factsheets/fs006430t.htm (16/5/2002).

EPA 2000c. Biopesticide Fact Sheet. Bacillus thuringiensis subsp. kurstaki CryIAc and its controlling sequences as expressed in cotton. US Environmental Protection Agency, Washington, DC. http://www.epa.gov/pesticides/biopesticides/factsheets/ fs006445t.htm (16/5/2002).

Fitt, G.P.; Wilson, L.J. 2000: Genetic engineering in IPM: Bt cotton. In: Kennedy, G.G.; Sutton, T.B. ed. Emerging technologies for integrated pest management. APS Press, The American Phytopathological Society, St. Paul, Minnesota. Pp. $108-125$.

Gianessi, L.P.; Carpenter, J.E. 1999: Agricultural biotechnology: insect control benefits. National Center for Food and Agricultural Policy, Washington, DC. http:// www.ncfap.org/ (16/5/2002). 
Gianessi, L.P.; Silvers, C.S. 2001: The potential for biotechnology to improve crop pest management in the US. 30 Crop Study. National Center for Food and Agricultural Policy, Washington, DC. http://www.ncfap.org/ (16/5/2002).

Glare, T.R.; O'Callaghan, M.O. 2000: Bacillus thuringiensis: Biology, ecology and safety. Wiley, Chichester. $350 \mathrm{p}$.

Gould, F. 1994: Potential problems with high-dose strategies for pesticidal engineered crops. Biocontrol Sci. Technol. 4: 451-461.

Gould, F. 2000: Testing Bt refuge strategies in the field. Nature Biotechnol. 18: 266.

Groot, A.T.; Dicke, M. 2001: Transgenic crops in an agro-ecological context: Multitrophic effects of insect-resistant plants. Wageningen University Press, the Netherlands. $76 \mathrm{p}$.

Halcomb, J.L.; Benedict, J.H.; Cook, B.; Ring, D.R. 1996: Survival and growth of bollworm and tobacco budworm on nontransgenic and transgenic cotton expressing a CryIA insecticidal protein (Lepidoptera: Noctuidae). Environ. Entomol. 25: 250255.

Hilbeck, A. 2002: Transgenic host plant resistance and non-target effects. In: Letourneau, D.K.; Burrows, B.E. ed. Genetically modified organisms. Assessing Environmental and Human Health Effects. CRC Press, Boca Raton. Pp. 167-185.

Hilder, V.A.; Boulter, D. 1999: Genetic engineering of crop plants for insect resistance - a critical review. Crop Prot. 18: 177-191.

Hyde, J.; Martin, M.A.; Preckel, P.V.; Edwards, C.R. 1999: The economics of Bt corn: valuing protection from the European corn borer. Rev. Agric. Econ. 21: 442-454.

James, C. 2002: Global review of commercialised transgenic crops: 2001, ISAAA Briefs No. 24. International Service for the Acquisition of Agri-biotech Applications, Ithaca, NY. http://www.isaaa.org/publications/briefs/Brief_24.htm (16/5/2002)

Jepson, P.C.; Croft, B.A.; Pratt, G.E. 1994: Test systems to determine the ecological risks posed by toxin release from Bacillus thuringiensis genes in crop plants. Mol. Ecol. 3: 81-89.

Letourneau, D.K.; Hagen, J.A.; Robinson, G.S. 2002: Bt-crops: evaluating benefits under cultivation and risks from escaped transgenes in the wild. In: Letourneau, D.K.; Burrows, B.E. ed. Genetically modified organisms. Assessing Environmental and Human Health Effects. CRC Press, Boca Raton. Pp. 33-98.

Losey, J.E.; Obrycki, J.J.; Hufbauer, R.A. 2002: Impacts of genetically engineered crops on non-target herbivores: Bt-corn and monarch butterflies as a case study. In: Letourneau, D.K.; Burrows, B.E. ed. Genetically modified organisms. Assessing environmental and human health effects. CRC Press, Boca Raton. Pp. 143-165.

MacIntyre, A.A.; Alison, N.; Penman, D.R. 1989: Pesticides: issues and options for New Zealand. Ministry for the Environment, Wellington, N.Z. 208 p.

McGaughey, W.H.; Gould, F.; Gelernter, W. 1998: Bt resistance management. Nature Biotechnol. 16: 144-146.

Malone, L.A.; Burgess, E.P.J.; Gatehouse, H.S.; Voisey, C.R.; Tregidga, E.L.; Philip, B.A. 2001: Effects of ingestion of a Bacillus thuringiensis toxin and a trypsin inhibitor on honey bee flight activity and longevity. Apidologie 32: 57-68.

Obrycki, J.J.; Losey, J.E.; Taylor, O.R.; Jesse, L.C.H. 2001: Transgenic insecticidal corn: beyond insecticidal toxicity to ecological complexity. BioScience 51: 353361.

Obrycki, J.J. 2001: Response from Obrycki and colleagues. BioScience 51: 903-905.

Ortman, E.E.; Barry, B.D.; Buschman, L.L.; Calvin, D.D.; Carpenter, J.; Dively, G.P.; Foster, J.E.; Fuller, B.W.; Hellmich, R.L.; Higgins, R.A.; Hunt, T.E.; Munkvold, G.P.; Ostlie, K.R.; Rice, M.E.; Rousch, R.T.; Sears, M.K.; Shelton, A.M.; Siegfried, B.D.; Sloderbeck, P.E.; Steffey, K.1.; Turpin, F.T.; Wedberg, J.L. 2001: Transgenic insecticidal corn: the agronomic and ecological ratinale for its use. BioScience 51: 900-902. 
Sharma H.C.; Ortiz, R. 2000: Transgenics, pest management, and the environment. Current Science 79: 421-437.

Shelton, A.M.; Tang, J.D.; Rousch, R.T.; Metz, T.D.; Earle, E.D. 2000: Field tests on managing resistacne to Bt-engineered plants. Nature Biotechnol. 18: 339-342.

Shelton, A.M.; Zhao, J.-Z. Roush, R.T. 2002: Economic, ecological, food safety, and social consequences of the deployment of Bt transgenic plants. Ann. Rev. Entomol. 47: 845-881.

Storer, N.P.; Van Duyn, J.W.; Kennedy, G.C. 2001: Life history traits of Helicoverpa zea (Lepidoptera: Noctuidae) on non-Bt and transgenic Bt corn hybrids in eastern North Carolina. J. Econ. Entomol. 94: 1268-1279.

Suckling, D.M.; McKenna, C.; Walker, J.T.S. 2002: IPM in NZ Horticulture. Global Perspectives in Integrated Pest Management. CABI. In press.

Tabashnik, B.E.; Patin, A.L.; Dennehy, T.J.; Liu, Y.-B.; Carriere, Y; Sims, M.A. 2000a: Frequency of resistance to Bacillus thuringiensis in field populations of pink bollworm. Proc. Natl Acad. Sci. U.S.A. 97: 12980-12984.

Tabashnik, Liu, Y.-B.; de Maagd, R.A.; Dennehy, T.J. 2000b: Cross-resistance of pink bollworm (Pectinophora gossypiella) to Bacillus thuringiensis toxins. Appl. Environ. Microbiol. 66: 4582-4584.

Tabashnik, B.E.; Johnson, K.W.; Engelman, J.T.; Baum, J.A. 2000c: Cross resistance to Bacillus thuringiensis toxin Cry1Ja in a strain of diamondback moth adapted to artificial diet. J. Invert. Path. 76: 81-83.

van Emden, H.F. 1999: Transgenic host plant resistance to insects - some reservations. Ann. Entomol. Soc. America. 92: 788-797.

Walker, J.T.S.; Mantelow, D.W.L.; Wearing, C.H.; Lo, P.I.; Suckling, D.M. 2001: Development of Integrated Fruit Production programmes in the New Zealand horticultural industry. IOBC/WPRS Bull. 24 (5): 39-44. 